\title{
sUPAR as a prognostic biomarker in sepsis
}

\author{
Katia Donadello, Sabino Scolletta, Cecilia Covajes and Jean-Louis Vincent ${ }^{*}$
}

\begin{abstract}
Sepsis is the clinical syndrome derived from the host response to an infection and severe sepsis is the leading cause of death in critically ill patients. Several biomarkers have been tested for use in diagnosis and prognostication in patients with sepsis. Soluble urokinase-type plasminogen activator receptor (sUPAR) levels are increased in various infectious diseases, in the blood and also in other tissues. However, the diagnostic value of suPAR in sepsis has not been well defined, especially compared to other more established biomarkers, such as C-reactive protein (CRP) and procalcitonin (PCT). On the other hand, suPAR levels have been shown to predict outcome in various kinds of bacteremia and recent data suggest they may have predictive value, similar to that of severity scores, in critically ill patients. This narrative review provides a descriptive overview of the clinical value of this biomarker in the diagnosis, prognosis and therapeutic guidance of sepsis.
\end{abstract}

Keywords: infection, sepsis, biomarker, disease severity, case fatality, outcome, soluble urokinase-type plasminogen activator receptor, suPAR

\section{Introduction}

Sepsis is defined as the clinical syndrome resulting from the presence of both infection and a systemic inflammatory response [1]. Sepsis involves the activation of inflammatory and anti-inflammatory mediators, cellular and humoral reactions, and micro- and macro-circulatory alterations. Despite improvements in the management of critically ill patients with serious infections, sepsis is still the leading cause of death in critically ill patients [2]. Early diagnosis of sepsis is vital because rapid, appropriate therapy is associated with improved outcomes [3]. There is, therefore, a need for better techniques to facilitate the diagnosis of sepsis and to monitor its course.

\footnotetext{
* Correspondence: jlvincen@ulb.ac.be

Department of Intensive Care, Erasme University Hospital, Université Libre de Bruxelles, 808, route de Lennik 1070, Brussels, Belgium
}

Various biomarkers, biological molecules that are characteristic of normal or pathogenic processes and can be easily and objectively measured, have been proposed as being of potential use for sepsis diagnosis, therapeutic guidance, and/or prognostication [4,5], although their exact role remains undefined [3]. The two biomarkers that have been most widely studied and used in patients with sepsis are C-reactive protein (CRP) and procalcitonin (PCT). Levels of both these biomarkers have been demonstrated to be raised in patients with sepsis making them useful diagnostic indicators [6,7]. Importantly, because they lack specificity for sepsis and levels may be raised in other inflammatory diseases, these biomarkers are more useful for ruling out sepsis than for ruling it in, that is, a completely normal value makes a diagnosis of sepsis very unlikely. PCT, in particular, has also been used for therapeutic guidance in patients with various types of infection [7].

Recently, the soluble form of the urokinase-type plasminogen activator receptor (suPAR) has attracted scientific interest because it seems to discriminate better than some other biomarkers among patients with different severities of illness [8]. In this narrative review, we discuss the available literature on suPAR in sepsis and provide a descriptive overview of the clinical value of this biomarker in the diagnosis, prognosis and therapeutic guidance of sepsis.

\section{Structure and history of suPAR}

The urokinase-type plasminogen activator (uPA) system consists of a protease, a receptor (UPAR) and inhibitors. In 1990, uPAR was cloned [9] and, in 1991, Ploug et al. identified its soluble form (suPAR) [10]. UPAR is expressed on various cell types including neutrophils, lymphocytes, monocytes/macrophages, endothelial and tumor cells. After cleavage from the cell surface, suPAR can be found in the blood and other organic fluids in all individuals, existing in three forms (I-III, II-III and I) that have different properties related to their structural differences (Figure 1) [11]. suPAR takes part in various immunological functions, including cell adhesion, migration, chemotaxis, proteolysis, immune activation, tissue remodeling, invasion and signal transduction [12]. Serum 


\section{Cell membrane}

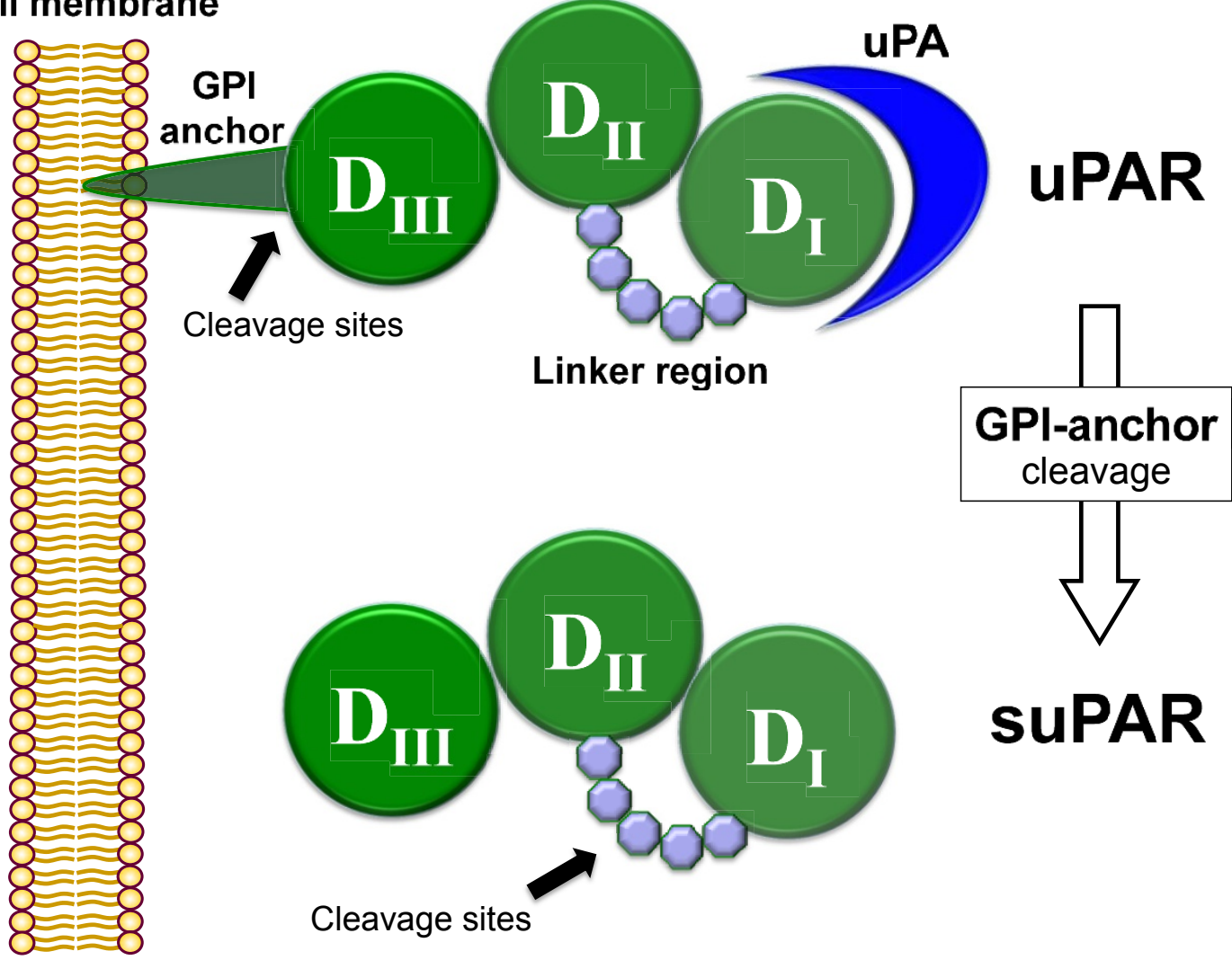

Figure 1 Schematic of the structure of uPAR, the mechanism of cleavage and the formation of suPAR. DI, DII, DIII represent the three homologous domains of suPAR.

concentrations are stable throughout the day with limited circadian changes and are not influenced by fasting. Cerebrospinal fluid (CSF), urine and serum (after centrifugation of whole blood) levels can be measured with a monoclonal antibody double sandwich enzyme-linked immunosorbent assay (ELISA) using commercial kits (for example, R \&D Systems, Minneapolis, MN; suPARnostic ${ }^{\mathrm{TM}}$, Virogates, Copenhagen, Denmark). In healthy adults, the median value of suPAR has been cited as 1.5 $\mathrm{ng} / \mathrm{ml}$ (range: 1.2 to $1.9 \mathrm{ng} / \mathrm{ml}, \mathrm{N}=44$ ) [13], or $2.6 \mathrm{ng} / \mathrm{ml}$ (range: 1.5 to $4.0 \mathrm{ng} / \mathrm{ml}, \mathrm{N}=31$ ) [14].

\section{suPAR as a diagnostic marker of sepsis}

As early as 1995 , elevated plasma suPAR levels were reported in a small group of septic intensive care unit (ICU) patients [15]. During endotoxemia, suPAR expression is increased on peripheral blood mononuclear cells $[16]$ as on monocytes and granulocytes $[17,18]$. However, although suPAR serum concentrations were increased after administration of high-dose endotoxin [16], low-dose endotoxin did not significantly increase plasma suPAR levels in vivo [16]. On the other hand, PCT and CRP are strongly induced by endotoxin [19-21], which may explain their enhanced usefulness for the diagnosis of bacterial infection.

In 100 patients with Crimean-Congo hemorrhagic fever (CCHF) [22], serum suPAR levels were significantly higher in patients with infection than in healthy controls; the optimum diagnostic cut-off value was $3.06 \mathrm{ng} / \mathrm{ml}$, with an area under the receiver operating characteristic curve (AUROC) of 0.94. In a cohort of 156 patients with suspected sepsis [23], 96 of whom had bacterial infection, AUROCs for diagnosis of bacterial sepsis were 0.72 for PCT, 0.81 for CRP and only 0.50 for suPAR levels, suggesting that suPAR was of less value for diagnosis than these other biomarkers.

suPAR levels may be measured in other milieu than blood. In 183 patients clinically suspected of having meningitis, suPAR levels were significantly higher in the CSF of patients with proven central nervous system (CNS) infection than in those without [24]. There were no differences in CSF suPAR levels between patients with meningitis and those with encephalitis but levels were significantly higher in patients with purulent (especially in pneumococcal infection) than in those with lymphocytic meningitis. A cut-off value of $1.50 \mathrm{mcg} / \mathrm{l}$ distinguished purulent from 
viral meningitis. Similar findings were reported in a smaller study of just 12 patients with bacterial meningitis [25]. Nevertheless, because of the relatively low diagnostic sensitivity and specificity, the routine use of CSF suPAR measurement in CNS disease cannot be recommended at the present time.

A study by Koch et al. [26] is currently the only published report evaluating the diagnostic and prognostic impact of suPAR in a large cohort of critically ill patients $(n=273)$. Critically ill patients had higher serum suPAR concentrations at admission than healthy controls. The AUROC for prediction of sepsis was 0.62 , compared to 0.86 for CRP and 0.78 for PCT. suPAR concentrations were closely related to other sepsis markers, including CRP, PCT, and tumor necrosis factor $\alpha$ levels. suPAR levels were also inversely related to renal function (as assessed by cystatin $C$, creatinine or urea levels), reflecting the renal clearance of suPAR; they were inversely related to albumin, and directly related to markers of cholestasis (for example, bilirubin, alkaline phosphatase). In an ongoing study in critically ill patients [27], we have found that a cut-off value of $5.5 \mathrm{ng} / \mathrm{ml}$ has a sensitivity of $75 \%$ and specificity of $72 \%$ for diagnosing sepsis. In this study, suPAR levels were correlated to CRP levels in the whole study population, but not in the group of patients with sepsis.

Table 1 summarizes the available data on the diagnostic value of suPAR in sepsis. Taking all these results into consideration, it appears that suPAR has poor accuracy in diagnosing sepsis compared to CRP and PCT, making suPAR of limited value as a diagnostic marker of sepsis.

\section{suPAR as a prognostic biomarker in sepsis}

Biomarkers are relevant in clinical practice not only for their ability to diagnose a pathological condition, but also for predicting morbidity and outcome. Several studies have indicated that suPAR concentrations may reflect the severity of infection and have reported that they are associated with a worse outcome in a range of non-infectious and infectious diseases (Table 2). An association with mortality has been reported in patients with malaria [28], tuberculosis [29], and human immunodeficiency virus (HIV) infection [30-32]. In a study of 314 HIV-1 infected patients, the median serum suPAR value was $3.69 \mathrm{ng} / \mathrm{ml}$ [33]. Serum levels were higher in patients with lower CD4 counts, higher viral loads, and a higher incidence of AIDS-related death. There was a weak but significant negative correlation between suPAR levels and CD4 count, and a weak positive correlation between suPAR levels and viral load. The survival curves were significantly different for patients with low, medium and high suPAR levels, showing lower survival rates as suPAR levels increased. In a multivariate Cox regression model,
suPAR levels were a stronger predictor of survival than CD4 count and viral load [33].

In a small series of patients with CCHF, serum suPAR levels were related to renal and hepatic function and were of prognostic value [22]. No analysis for confounding factors was made by the authors of this study, but recently, using linear regression analysis, Koch et al. [26] showed that renal and liver function were independent predictors of elevated suPAR levels. CSF suPAR levels in patients with meningitis were positively correlated with age, CSF leukocyte and neutrophil count, CSF/blood-glucose ratio, altered Glasgow Coma Scale score, and need for assisted ventilation [24]. CSF suPAR levels were also higher in non-survivors compared to survivors.

Kofoed et al. [34] compared the prognostic value of suPAR to that of other biomarkers (soluble triggering receptor expressed on myeloid cells (sTREM-1) and macrophage migration inhibitory factor (MIF)) and of the Simplified Acute Physiology Score (SAPS) II and Sequential Organ Failure Assessment (SOFA). Of 151 patients with possible sepsis, $64 \%$ had a bacterial infection. suPAR levels (measured using the suPARnostic assay, cut-off value $>6.61 \mathrm{mcg} / \mathrm{L}$ ) had a better prognostic value than PCT and CRP, equal to that of the admission SOFA score and almost as good as the SAPS II score; the combination of suPAR and age had a better prognostic value than the SAPS II score alone.

In a multicenter prospective study of 141 adult patients with Streptococcus pneumoniae bacteremia, Wittenhagen and colleagues [14] found that suPAR levels at admission were significantly increased compared to those of healthy controls. suPAR levels were higher in the $17 \%$ of patients who died from the infection than in those who survived. In a logistic multivariate regression analysis including clinical variables with a prognostic value (hypotension, renal failure, cerebral symptoms at admission, alcohol abuse), only suPAR levels above $10 \mathrm{ng} / \mathrm{ml}$ independently predicted mortality. The very high suPAR levels were similar to those found in patients with Gram-negative urosepsis [35] and in patients with bacterial meningitis [25].

Huttunen and colleagues [8] investigated suPAR levels as a predictor of disease severity and mortality in 132 patients with bacteremia caused by Staphylococcus aureus, Streptococcus (pneumonia and $\beta$-hemolytic) or Escherichia coli. The best mortality predictive cut-off level was $11 \mathrm{ng} /$ $\mathrm{ml}$. During the 30-day follow-up period, 18 patients died; 15 of them had suPAR levels above $11 \mathrm{ng} / \mathrm{ml}$, compared to only three with levels below $11 \mathrm{ng} / \mathrm{ml}$. Levels above this cut-off were also associated with disease severity (hypotension, need for vasopressors or mechanical ventilation, SOFA score $\geq 4$ ). Logistic regression analysis gave an odds ratio for mortality of 16.1 (95\% confidence interval [CI] 4.3 to 59.9), which remained significant after adjustment for potential confounders (for example, liver disease and 
Table 1 Studies evaluating the diagnostic value of soluble urokinase-type plasminogen activator receptor (suPAR) levels

\begin{tabular}{|c|c|c|c|c|c|c|}
\hline $\begin{array}{l}\text { First author, } \\
\text { publication } \\
\text { date [ref] }\end{array}$ & Type & Pathology & Patients & Period & Main results & Comments \\
\hline $\begin{array}{l}\text { Kofoed, } 2007 \\
\quad[23]\end{array}$ & Prospective & $\begin{array}{l}\text { Suspected } \\
\text { sepsis }\end{array}$ & $\begin{array}{l}156 \text { adult, samples taken at } \\
\text { ED admission }\end{array}$ & 12 months & $\begin{array}{l}\text { AUC bacterial sepsis: } \\
\text { sUPAR } 0.5, \text { PCT } 0.72 \\
\text { CRP } 0.81\end{array}$ & \\
\hline Yilmaz, 2010 [22] & Retrospective & $\mathrm{CCHF}$ & $\begin{array}{l}100 \text { infected adult pts vs } \\
\text { volunteers. } \\
\text { Samples taken at hospital } \\
\text { admission }\end{array}$ & $\begin{array}{l}2006-2009 \\
38 \text { months }\end{array}$ & 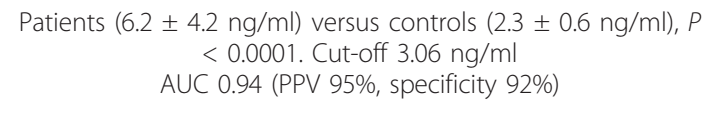 & No other infections studied \\
\hline $\begin{array}{l}\text { Østergaard, } 2004 \\
{[24]}\end{array}$ & Prospective & CNS infection & $\begin{array}{l}183 \text { adults, samples taken at } \\
\text { admission }\end{array}$ & 1988 to 2002 & $\begin{array}{c}\text { Higher CSF levels in infected patients and in patients with } \\
\text { purulent meningitis versus those with lymphocytic } \\
\text { meningitis }(P<0.001)\end{array}$ & $\begin{array}{l}\text { Low sensitivity and specificity }(69 \% \\
\text { and } 71 \%) \text { with cut-off value of } 1.50 \\
\text { mcg/l }\end{array}$ \\
\hline Koch, 2011 [26] & Prospective & $\begin{array}{l}\text { Critical illness } \\
\text { medical ICU }\end{array}$ & $\begin{array}{l}273 \text { adults, } 197 \text { septic } \\
\text { patients, samples taken at } \\
\text { ICU admission }\end{array}$ & Undefined & AUC sepsis suPAR 0.615 PCT 0.857 CRP 0.780 & $\begin{array}{c}\text { Correlation with renal and hepatic } \\
\text { function }\end{array}$ \\
\hline $\begin{array}{l}\text { Donadello, } 2011 \\
{[27]}\end{array}$ & Prospective & $\begin{array}{l}\text { Critical illness } \\
\text { medico-surgical } \\
\text { ICU }\end{array}$ & $\begin{array}{l}152 \text { adults, } 55 \text { septic } \\
\text { patients. } \\
\text { Samples taken at ICU } \\
\text { admission }\end{array}$ & $\begin{array}{l}\text { December } \\
2010 \text { to } \\
\text { March } 2011\end{array}$ & $\begin{array}{l}\text { AUC sepsis } 0.75 \text { (95\% Cl } 0.66 \text { to } 0.83) \text {; correlation with CRP in } \\
\text { global population ( } r=0.48) \text {, not in septic patients }(r=0.18)\end{array}$ & Preliminary data \\
\hline
\end{tabular}
predictive value. 
Table 2 Studies evaluating the prognostic value of soluble urokinase-type plasminogen activator receptor (suPAR) levels

\begin{tabular}{|c|c|c|c|c|c|c|}
\hline First author & Type & Pathology & Patients & Period & Main results & Comments \\
\hline $\begin{array}{l}\text { Sidenius, } \\
2000[33]\end{array}$ & Retrospective & HIV & $\begin{array}{l}314 \text { adults, samples taken at } \\
\text { enrollment }\end{array}$ & $\begin{array}{c}1991 \text { to } \\
1992\end{array}$ & $\begin{array}{c}\text { Range of suPAR levels } 1.15 \text { to } 15.60 \mathrm{ng} / \mathrm{ml} \text {. } \\
\text { Low }(<3.28 \mathrm{ng} / \mathrm{ml}) \text {, medium }(3.28-4.19 \mathrm{ng} / \mathrm{ml}) \text { and } \\
\text { high }(>4.19 \mathrm{ng} / \mathrm{ml}) \text { suPAR levels related to increasing } \\
\text { risk of AIDS-related death. Hazard ratio for death was } \\
2.2 \text { for medium suPAR levels (vs low) and } 4.7 \text { for high } \\
\text { suPAR levels }\end{array}$ & $\begin{array}{l}\text { Samples were not all obtained at } \\
\text { enrollment }\end{array}$ \\
\hline $\begin{array}{l}\text { Eugen-Olsen, } \\
2002[29]\end{array}$ & Retrospective & $\begin{array}{l}\text { Mycobacterium } \\
\text { tuberculosis }\end{array}$ & $\begin{array}{l}262 \text { adults, samples taken at } \\
\text { enrollment in a cohort based on } \\
\text { suspicion of active tuberculosis } \\
8 \text { month-follow-up for } 101 \text { patients }\end{array}$ & $\begin{array}{l}1996 \\
\text { to1998 }\end{array}$ & $\begin{array}{c}\text { Elevated levels in active TB. } 1.25 \text { increase in mortality } \\
\text { per ng increase in suPAR. }\end{array}$ & Not all patients were followed-up \\
\hline $\begin{array}{l}\text { Ostrowski, } \\
2005[30]\end{array}$ & Prospective & HIV & $\begin{array}{l}59 \text { healthy individuals }+99 \text { HIV } \\
\text { patients. Samples taken at study } \\
\text { inclusion-median time from first } \\
\text { positive HIV antibody test was } 8 \text { ( } 5 \text { to } \\
\text { 9) years }\end{array}$ & $\begin{array}{l}2000 \text { to } \\
2001\end{array}$ & $\begin{array}{c}\text { Higher levels predicted increased mortality risk. } \\
\text { suPAR(I-III) and (II-III) are independent predictors of } \\
\text { mortality }\end{array}$ & $\begin{array}{l}\text { Measurement of suPAR (II-III),(II-III) and } \\
\text { (I) forms }\end{array}$ \\
\hline $\begin{array}{l}\text { Ostrowski, } \\
2005[28]\end{array}$ & Prospective & Malaria & $\begin{array}{l}645 \text { African children with clinical } \\
\text { symptoms of malaria: } 478 \text { had } \\
\text { malaria. } 14 \text { healthy children as controls. } \\
\text { Samples taken at hospital admission. }\end{array}$ & $\begin{array}{l}\text { June to } \\
\text { August of } \\
2000 \text { and } \\
2001\end{array}$ & $\begin{array}{l}\text { Highest concentrations in non-survivors (11) or with } \\
\text { complicated malaria. } 1 \mathrm{ng} / \mathrm{mL} \text { increase in suPAR } \\
\text { concentration was associated with increased mortality } \\
\text { (OR 1.42) }\end{array}$ & $\begin{array}{l}\text { Low platelet count and hemoglobin } \\
\text { level, high neutrophil count were } \\
\text { independent predictors of high } \\
\text { plasma concentration of suPAR }\end{array}$ \\
\hline $\begin{array}{l}\text { Lawn, } 2007 \\
\quad[32]\end{array}$ & Prospective & HIV & $\begin{array}{l}293 \text { adults. } \\
\text { Samples taken at enrollment for } \\
\text { antiretroviral treatment }\end{array}$ & $\begin{array}{l}\text { Sept } 2002 \\
\text { to Feb } \\
2005 \\
5 \text { month } \\
\text { follow-up } \\
\quad \text { after } \\
\text { enrollment }\end{array}$ & $\begin{array}{l}\text { Significantly higher suPAR levels in non survivors. } \\
\text { Log10 sUPAR strongly associated with death }\end{array}$ & $\begin{array}{l}\text { No discriminatory cut-off point to } \\
\text { provide clinically useful information }\end{array}$ \\
\hline $\begin{array}{l}\text { Yilmaz, } 2010 \\
{[22]}\end{array}$ & Retrospective & $\mathrm{CCHF}$ & $\begin{array}{c}100 \text { adults, samples taken at hospital } \\
\text { admission }\end{array}$ & $\begin{array}{l}2006 \text { to } \\
2009 \\
38 \text { months }\end{array}$ & Cut-off value of $10.6 \mathrm{ng} / \mathrm{ml}$ AUC 0.97 & $\begin{array}{l}\text { Only } 5 / 100 \text { deaths } \\
\text { No comparison with other infections }\end{array}$ \\
\hline $\begin{array}{l}\text { Kofoed, } 2008 \\
{[34]}\end{array}$ & $\begin{array}{l}\text { Retrospective } \\
\text { sample } \\
\text { analysis }\end{array}$ & $\begin{array}{l}\text { Suspected } \\
\text { sepsis } \\
64 \% \text { bacterial } \\
\text { infection }\end{array}$ & $\begin{array}{c}151 \text { adults, samples taken at ED } \\
\text { admission }\end{array}$ & 12 months & $\begin{array}{c}\text { Mortality: } \\
\text { suPAR AUROC 0.80 (sensitivity } 89 \% \text {, specificity } 63 \% \text {, } \\
95 \% \mathrm{Cl} 0.69-0.92 \text { ). } \\
\text { sUPAR and age AUROC } 0.92 \text { (sensitivity } 100 \%, \\
\text { specificity } 78 \%, 95 \% \text { Cl } 0.86-0.97 \text { ) }\end{array}$ & PCT and CRP had no prognostic value \\
\hline $\begin{array}{l}\text { Ostergaard, } \\
2004[24]\end{array}$ & Prospective & CNS infection & $\begin{array}{l}183 \text { adults. } \\
\text { Samples taken at admission }\end{array}$ & $\begin{array}{l}1988 \text { to } \\
2002\end{array}$ & $\begin{array}{c}\text { Positive correlation of CSF suPAR levels with } \\
\text { prognosis; cut-off } 3.1 \mathrm{mcg} / \mathrm{l} \text { had OR for death of } 11.9 \\
(95 \% \mathrm{Cl} 1.4-106)\end{array}$ & $\begin{array}{l}\text { Multivariate analysis was not possible } \\
\text { due to small number of deaths }\end{array}$ \\
\hline $\begin{array}{l}\text { Wittenhagen, } \\
2004[14]\end{array}$ & $\begin{array}{l}\text { Multicenter } \\
\text { prospective } \\
\text { study }\end{array}$ & $\begin{array}{l}\text { S. Pneumonia } \\
\text { bacteremia }\end{array}$ & $\begin{array}{l}141 \text { adults. Samples taken at hospital } \\
\text { admission }\end{array}$ & $\begin{array}{l}1999 \text { to } \\
2001 ; 21 \\
\text { months }\end{array}$ & $\begin{array}{c}\text { Higher suPAR levels in patients compared to healthy } \\
\text { volunteers (median 5.5, range } 2.4 \text { to } 21.0 \mathrm{ng} / \mathrm{ml} \text { ). } \\
\text { Levels }>10 \mathrm{ng} / \mathrm{ml} \text { independent predictor of mortality } \\
\text { (OR 13, specificity } 95 \% \text {, sensitivity } 38 \% \text {, NPV } 88 \% \text {, PPV } \\
60 \% \text { ) }\end{array}$ & $\begin{array}{l}\text { Logistic multivariate regression } \\
\text { analysis }\end{array}$ \\
\hline $\begin{array}{l}\text { Huttunen, } \\
2011[8]\end{array}$ & $\begin{array}{l}\text { Prospective } \\
\text { cohort study }\end{array}$ & Bacteremia & $\begin{array}{l}132 \text { adults. } \\
\text { Samples taken at day } 1 \text { after the first } \\
\text { positive blood culture }\end{array}$ & $\begin{array}{l}\text { June } 1999 \\
\text { to Feb } \\
2004\end{array}$ & $\begin{array}{c}11 \mathrm{ng} / \mathrm{ml} \text { AUROC } 0.84 \text { ( } 95 \% \mathrm{Cl} 0.76 \text { to } 0.93 \text {, sensitivity } \\
83 \% \text {, specificity } 76 \% \text { ). } \\
\text { Higher levels associated with disease severity. } \\
\text { OR for mortality } 16.1 \text { ( } 95 \% \mathrm{Cl} 4.3 \text { to } 59.9 \text {-logistic } \\
\text { regression analysis) }\end{array}$ & $\begin{array}{l}\text { Plasma samples were not taken at } \\
\text { admission }\end{array}$ \\
\hline
\end{tabular}


Table 2 Studies evaluating the prognostic value of soluble urokinase-type plasminogen activator receptor (suPAR) levels (Continued)

\begin{tabular}{|c|c|c|c|c|c|c|}
\hline $\begin{array}{l}\text { Molkanen, } \\
2011[36]\end{array}$ & $\begin{array}{l}\text { Retrospective } \\
\text { sample } \\
\text { analysis }\end{array}$ & $\begin{array}{l}\text { S. aureus } \\
\text { bacteremia }\end{array}$ & $\begin{array}{l}59 \text { adults. } \\
\text { Samples taken on day } 3 \text {, after positive } \\
\text { blood culture }\end{array}$ & & $\begin{array}{l}\text { sUPAR AUROC for mortality } 0.754(95 \% \mathrm{Cl} 0.615 \text { to } \\
\text { O.894, } P=0.003) \\
\text { CRP AUROC } 0.596 . \\
\text { Cut-off } 9.25 \mathrm{ng} / \mathrm{ml}\end{array}$ & $\begin{array}{c}\text { Plasma samples not taken at } \\
\text { admission }\end{array}$ \\
\hline $\begin{array}{c}\text { Koch, } 2011 \\
{[26]}\end{array}$ & Prospective & $\begin{array}{l}\text { Critical illness } \\
\text { medical ICU }\end{array}$ & $\begin{array}{l}273 \text { adults, } 197 \text { septic. } \\
\text { Samples taken at ICU admission }\end{array}$ & Undefined & 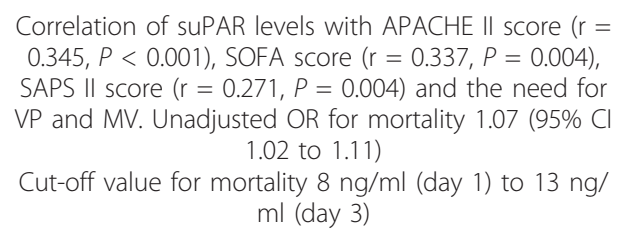 & $\begin{array}{c}\text { AUROC for ICU/overall survival larger } \\
(0.68 / 0.64) \text { than CRP }(0.52 / 0.53), \text { PCT } \\
(0.55 / 0.55) \text { and APACHE II }(0.54 / 0.60) \text {, } \\
\text { smaller than SAPS2 }(0.81 / 0.74)\end{array}$ \\
\hline $\begin{array}{l}\text { Donadello, } \\
2011[27]\end{array}$ & Prospective & $\begin{array}{l}\text { Critical illness, } \\
\text { medico-surgical } \\
\text { ICU }\end{array}$ & $\begin{array}{l}152 \text { adults, } 55 \text { septic. } \\
\text { Samples taken at ICU admission }\end{array}$ & $\begin{array}{l}\text { December } \\
2010 \text { to } \\
\text { March } \\
2011\end{array}$ & $\begin{array}{c}\text { Cut-off value } 6 \mathrm{ng} / \mathrm{ml} \text { (sensitivity } 63 \% \text {, specificity } 60 \%) \text {. } \\
\text { AUROC for mortality } 0.71 \text { ( } 95 \% \mathrm{Cl} 0.60 \text { to } 0.81 \text { ) in } \\
\text { overall population, in septic patients } 0.68(95 \% \mathrm{Cl} 0.47 \\
\text { to } 0.88 \text { ) }\end{array}$ & Preliminary data \\
\hline
\end{tabular}

AIDS: acquired immunodeficiency syndrome; APACHE II, Acute Physiology And Chronic Health Evaluation II; AUROC, area under the receiver operating characteristic curve; CCHF, Crimean Congo Hemorrhagic Fever; CNS, central nervous system; CRP, C-reactive protein; CSF, cerebrospinal fluid; ED, emergency department; MV, mechanical ventilation; NPV, negative predictive value; PCT, Procalcitonin; PPV, positive predictive value; OR, odds ratio; SAPS, Simplified Acute Physiology Score; SOFA, sequential organ failure assessment; TB, tuberculosis; VP, vasopressors. 
renal failure). Interestingly, a simple suPAR measurement predicted mortality at least as well as the SOFA score. High suPAR levels were similarly demonstrated to predict mortality in a small cohort of 59 patients with $S$. aureus bacteremia [36]. Serum suPAR levels on day 3 , after the first positive blood culture for S. aureus, were higher in the 19 patients who did not survive than in the 40 survivors and this difference persisted for 10 days. The best cut-off value was $9.25 \mathrm{ng} / \mathrm{ml}$.

In the study by Koch et al. in critically ill patients [26], suPAR levels were strongly linked to disease severity scores, such as Acute Physiology and Chronic Health Evaluation II (APACHE II), SOFA, and SAPS II scores, and with the need for mechanical ventilation and vasopressor support. Moreover, low suPAR levels at ICU admission, and on days 3 and 7 were strong predictors of ICU survival (ICU mortality $=28 \%$ ); after multivariate Cox regression analysis, suPAR levels retained a significant prognostic value. The best cut-off values for ICU survival were $8 \mathrm{ng} / \mathrm{ml}$ at day 1 and $13 \mathrm{ng} / \mathrm{ml}$ at day 3 . The AUROC for ICU/overall survival was larger for suPAR than for CRP, PCT and the APACHE II score, but smaller than for the SAPS II score. In our study in a mixed ICU cohort of patients we found that a cut-off value of $6 \mathrm{ng} / \mathrm{ml}$ had $63 \%$ sensitivity and $60 \%$ specificity for predicting ICU mortality with an AUROC of 0.71, but this was less than that of the APACHE II and SOFA scores. The suPAR AUROC for ICU mortality in septic patients was 0.68 [27].

Importantly, when interpreting the role of suPAR as a prognostic marker from the results of these different studies, it is important to take into consideration the time of blood sampling for suPAR measurement, as a stratification biomarker that is robust during the first days of admission is probably more useful than one that provides a prediction later in the ICU course. In summary, high levels of suPAR have been widely demonstrated to correlate with morbidity and outcome, supporting its value as a prognostic biomarker in various cohorts of infected patients; moreover several studies have reported that values greater than $10 \mathrm{ng} / \mathrm{ml}$ may be predictive of death.

\section{sUPAR for monitoring response to treatment}

Another potentially important use for a sepsis biomarker is in monitoring response to treatment. Adequate antimicrobial therapy is an essential aspect of management in patients with sepsis but duration of antimicrobial therapy is poorly defined. Prolonged and unnecessary use of antibiotics is associated with increased costs, adverse effects, and development of antimicrobial resistance. Hence, being able to follow response to therapy and guide antimicrobial use could be of value, as has been suggested for other biomarkers [37]. In this context, suPAR levels were followed in HIV patients enrolled in an antiretroviral treatment (ART) program in South Africa [32]. Plasma suPAR levels were the strongest independent predictor of short-term mortality risk but the results did not permit determination of a discriminatory threshold that could be used to triage patients. In patients with extra-pulmonary mycobacterial infection, suPAR levels remained elevated for more than six months during adequate anti-mycobacterial therapy [38], probably reflecting prolonged inflammatory activity in these patients. Furthermore, in a large cohort of critically ill patients, suPAR levels remained elevated during the first week of ICU treatment [26]. In a cohort of young children suspected of having Plasmodium falciparum malaria, levels of suPAR were decreased significantly after seven days of effective treatment compared to admission levels [39].

The available data suggest that sequential suPAR levels may be of use in following the acute response to treatment in patients with sepsis. However, the results from these relatively small studies need to be further validated in larger, multicenter trials before this approach can be recommended. Moreover, the heterogeneous nature of the current studies prevents any metaanalytic technique to derive an optimal range of values for prognostication.

\section{Conclusions}

The studies that have evaluated suPAR levels vary in the types of patient populations studied, the basal conditions of the patients, and the methods used to measure suPAR. The precise pathogenic involvement of suPAR and of its different forms during sepsis has, therefore, not been well defined. suPAR does not appear to be superior to other biomarkers, like CRP and PCT, in diagnosing sepsis. The independent predictive value of suPAR levels for outcome is more clearly established. suPAR levels may, therefore, be useful for triaging of patients for ICU admission, as high suPAR levels may indicate the need for more intense monitoring and treatment. The monitoring of suPAR levels during therapy needs further study to determine whether this biomarker could be of use in guiding therapeutic decisions. Finally, taking into account the present lack of a 'perfect' unique biomarker, further studies are warranted to evaluate the usefulness of combining several of the available biomarkers to improve their singular positive predictive values.

\section{List of abbreviations}

APACHE I: Acute Physiology and Chronic Health Evaluation II; ART: antiretroviral treatment; AUROC: area under the receiver operating characteristic curve: CCHF: Crimean-Congo hemorrhagic fever; CNS: central nervous system; CRP: C- reactive protein; CSF: cerebrospinal fluid; PCT: procalcitonin; SAPS: Simplified Acute Physiology Score; SOFA: sequential organ failure assessment; suPAR: soluble urokinase-type plasminogen activator receptor. 


\section{Authors' contributions}

KD and CC researched the literature and drafted the manuscript. SS critically revised the content. JLV corrected the draft manuscript and critically revised the content. All authors approved the final version.

\section{Competing interests}

The authors declare that they have no competing interests.

Received: 29 July 2011 Accepted: 5 January 2012

Published: 5 January 2012

\section{References}

1. Levy MM, Fink MP, Marshall JC, Abraham E, Angus D, Cook D, Cohen J, Opal SM, Vincent JL, Ramsay G: 2001 SCCM/ESICM/ACCP/ATS/SIS International Sepsis Definitions Conference. Crit Care Med 2003, 31:1250-1256.

2. Angus DC, Linde-Zwirble WT, Lidicker J, Clermont G, Carcillo J, Pinsky MR: Epidemiology of severe sepsis in the United States: analysis of incidence, outcome, and associated costs of care. Crit Care Med 2001, 29:1303-1310.

3. Dellinger RP, Levy MM, Carlet JM, Bion J, Parker MM, Jaeschke R, Reinhart K, Angus DC, Brun-Buisson C, Beale R, Calandra T, Dhainaut JF, Gerlach H, Harvey M, Marini JJ, Marshall J, Ranieri M, Ramsay G, Sevransky J, Thompson BT, Townsend S, Vender JS, Zimmerman JL, Vincent JL: Surviving Sepsis Campaign: international guidelines for management of severe sepsis and septic shock: 2008. Crit Care Med 2008, 36:296-327.

4. Marshall JC, Reinhart K: Biomarkers of sepsis. Crit Care Med 2009, 37:2290-2298.

5. Pierrakos C, Vincent JL: Sepsis biomarkers: a review. Crit Care 2010, 14:R15.

6. Vincent JL, Donadello K, Schmit X: Biomarkers in the critically ill patient: C-reactive protein. Crit Care Clin 2011, 27:241-251.

7. Schuetz P, Albrich WC, Mueller B: Procalcitonin for diagnosis of infection and guide to antibiotic decisions: past, present and future. BMC Med 2011, 9:107.

8. Huttunen R, Syrjanen J, Vuento R, Hurme M, Huhtala H, Laine J, Pessi T, Aittoniemi J: Plasma level of soluble urokinase-type plasminogen activator receptor as a predictor of disease severity and case fatality in patients with bacteraemia: a prospective cohort study. J Intern Med 2011, 270:32-40.

9. Roldan AL, Cubellis MV, Masucci MT, Behrendt N, Lund LR, Dano K, Appella E, Blasi F: Cloning and expression of the receptor for human urokinase plasminogen activator, a central molecule in cell surface, plasmin dependent proteolysis. EMBO I 1990, 9:467-474.

10. Ploug M, Ronne E, Behrendt N, Jensen AL, Blasi F, Dano K: Cellular receptor for urokinase plasminogen activator. Carboxyl-terminal processing and membrane anchoring by glycosyl-phosphatidylinositol. J Biol Chem 1991, 266:1926-1933.

11. Thuno M, Macho B, Eugen-Olsen J: suPAR: the molecular crystal ball. Dis Markers 2009, 27:157-172.

12. Eugen-Olsen J: suPAR as a marker of disease severity and risk of mortality in sepsis. J Intern Med 2011, 270:29-31.

13. Stephens RW, Pedersen AN, Nielsen HJ, Hamers MJ, Hoyer-Hansen G, Ronne E, Dybkjaer E, Dano K, Brunner N: ELISA determination of soluble urokinase receptor in blood from healthy donors and cancer patients. Clin Chem 1997, 43:1868-1876.

14. Wittenhagen P, Kronborg G, Weis N, Nielsen H, Obel N, Pedersen SS, Eugen-Olsen J: The plasma level of soluble urokinase receptor is elevated in patients with Streptococcus pneumoniae bacteraemia and predicts mortality. Clin Microbiol Infect 2004, 10:409-415.

15. Mizukami IF, Faulkner NE, Gyetko MR, Sitrin RG, Todd RF: Enzyme-linked immunoabsorbent assay detection of a soluble form of urokinase plasminogen activator receptor in vivo. Blood 1995, 86:203-211.

16. Ostrowski SR, Plomgaard P, Fischer CP, Steensberg AS, Moller K, HoyerHansen G, Pedersen BK, Ullum H: Interleukin-6 infusion during human endotoxaemia inhibits in vitro release of the urokinase receptor from peripheral blood mononuclear cells. Scand J Immunol 2005, 61:197-206.

17. Dekkers PE, ten Hove T, te Velde AA, van Deventer SJ, van der PT: Upregulation of monocyte urokinase plasminogen activator receptor during human endotoxemia. Infect Immun 2000, 68:2156-2160.

18. Juffermans NP, Dekkers PE, Verbon A, Speelman P, van Deventer SJ, van der PT: Concurrent upregulation of urokinase plasminogen activator receptor and $\mathrm{CD} 11 \mathrm{~b}$ during tuberculosis and experimental endotoxemia. Infect Immun 2001, 69:5182-5185.

19. Dandona P, Nix D, Wilson MF, Aljada A, Love J, Assicot M, Bohuon C: Procalcitonin increase after endotoxin injection in normal subjects. J Clin Endocrinol Metab 1994, 79:1605-1608.

20. de Kruif MD, Lemaire LC, Giebelen IA, Struck J, Morgenthaler NG, Papassotiriou J, Elliott PJ, van der PT: The influence of corticosteroids on the release of novel biomarkers in human endotoxemia. Intensive Care Med 2008, 34:518-522.

21. Kemna E, Pickkers $P$, Nemeth $E$, van der HH, Swinkels D: Time-course analysis of hepcidin, serum iron, and plasma cytokine levels in humans injected with LPS. Blood 2005, 106:1864-1866.

22. Yilmaz G, Mentese A, Kaya S, Uzun A, Karahan SC, Koksal I: The diagnostic and prognostic significance of soluble urokinase plasminogen activator receptor in Crimean-Congo hemorrhagic fever. J Clin Virol 2011, 50:209-211.

23. Kofoed $\mathrm{K}$, Andersen $\mathrm{O}$, Kronborg G, Tvede M, Petersen J, Eugen-Olsen J, Larsen K: Use of plasma C-reactive protein, procalcitonin, neutrophils, macrophage migration inhibitory factor, soluble urokinase-type plasminogen activator receptor, and soluble triggering receptor expressed on myeloid cells-1 in combination to diagnose infections: a prospective study. Crit Care 2007, 11:R38.

24. Ostergaard C, Benfield T, Lundgren JD, Eugen-Olsen J: Soluble urokinase receptor is elevated in cerebrospinal fluid from patients with purulent meningitis and is associated with fatal outcome. Scand I Infect Dis 2004, 36:14-19.

25. Winkler F, Kastenbauer S, Koedel U, Pfister HW: Role of the urokinase plasminogen activator system in patients with bacterial meningitis. Neurology 2002, 59:1350-1355.

26. Koch A, Voigt S, Kruschinski C, Sanson E, Duckers H, Horn A, Yagmur E, Zimmermann $\mathrm{H}$, Trautwein C, Tacke F: Circulating soluble urokinase plasminogen activator receptor is stably elevated during the first week of treatment in the intensive care unit and predicts mortality in critically ill patients. Crit Care 2011, 15:R63.

27. Donadello K, Covajes C, Scolletta S, Taccone FS, Santonocito C, Brimioulle S, Beumier M, Vannuffelen M, Gottin L, Vincent JL: Clinical value of suPAR, a new biomarker. Intensive Care Med 2011, 37:S199, (abst).

28. Ostrowski SR, Ullum H, Goka BQ, Hoyer-Hansen G, Obeng-Adjei G, Pedersen BK, Akanmori BD, Kurtzhals JA: Plasma concentrations of soluble urokinase-type plasminogen activator receptor are increased in patients with malaria and are associated with a poor clinical or a fatal outcome. J Infect Dis 2005, 191:1331-1341.

29. Eugen-Olsen J, Gustafson P, Sidenius N, Fischer TK, Parner J, Aaby P, Gomes VF, Lisse I: The serum level of soluble urokinase receptor is elevated in tuberculosis patients and predicts mortality during treatment: a community study from Guinea-Bissau. Int I Tuberc Lung Dis 2002, 6:686-692.

30. Ostrowski SR, Piironen T, Hoyer-Hansen G, Gerstoft J, Pedersen BK, Ullum H: High plasma levels of intact and cleaved soluble urokinase receptor reflect immune activation and are independent predictors of mortality in HIV-1-infected patients. J Acquir Immune Defic Syndr 2005, 39:23-31.

31. Djoba Siawaya JF, Ruhwald M, Eugen-Olsen J, Walzl G: Correlates for disease progression and prognosis during concurrent HIV/TB infection. Int J Infect Dis 2007, 11:289-299.

32. Lawn SD, Myer L, Bangani N, Vogt M, Wood R: Plasma levels of soluble urokinase-type plasminogen activator receptor (suPAR) and early mortality risk among patients enrolling for antiretroviral treatment in South Africa. BMC Infect Dis 2007, 7:41.

33. Sidenius N, Sier CF, Ullum H, Pedersen BK, Lepri AC, Blasi F, Eugen-Olsen J: Serum level of soluble urokinase-type plasminogen activator receptor is a strong and independent predictor of survival in human immunodeficiency virus infection. Blood 2000, 96:4091-4095.

34. Kofoed K, Eugen-Olsen J, Petersen J, Larsen K, Andersen O: Predicting mortality in patients with systemic inflammatory response syndrome: an evaluation of two prognostic models, two soluble receptors, and a macrophage migration inhibitory factor. Eur $J$ Clin Microbiol Infect Dis 2008, 27:375-383.

35. Florquin S, van den Berg JG, Olszyna DP, Claessen N, Opal SM, Weening JJ, van der PT: Release of urokinase plasminogen activator receptor during urosepsis and endotoxemia. Kidney Int 2001, 59:2054-2061. 
36. Molkanen T, Ruotsalainen E, Thorball CW, Jarvinen A: Elevated soluble urokinase plasminogen activator receptor (suPAR) predicts mortality in Staphylococcus aureus bacteremia. Eur I Clin Microbiol Infect Dis 2011, 30:1417-1424.

37. Hochreiter M, Kohler T, Schweiger AM, Keck FS, Bein B, von Spiegel T, Schroeder S: Procalcitonin to guide duration of antibiotic therapy in intensive care patients: a randomized prospective controlled trial. Crit Care 2009, 13:R83.

38. Ostrowski SR, Ravn P, Hoyer-Hansen G, Ullum H, Andersen AB: Elevated levels of soluble urokinase receptor in serum from mycobacteria infected patients: still looking for a marker of treatment efficacy. Scand J Infect Dis 2006, 38:1028-1032.

39. Perch M, Kofoed P, Fischer TK, Co F, Rombo L, Aaby P, Eugen-Olsen J: Serum levels of soluble urokinase plasminogen activator receptor is associated with parasitemia in children with acute Plasmodium falciparum malaria infection. Parasite Immunol 2004, 26:207-211.

Pre-publication history

The pre-publication history for this paper can be accessed here: http://www.biomedcentral.com/1741-7015/10/2/prepub

doi:10.1186/1741-7015-10-2

Cite this article as: Donadello et al: suPAR as a prognostic biomarker in sepsis. BMC Medicine 2012 10:2.

\section{Submit your next manuscript to BioMed Central} and take full advantage of:

- Convenient online submission

- Thorough peer review

- No space constraints or color figure charges

- Immediate publication on acceptance

- Inclusion in PubMed, CAS, Scopus and Google Scholar

- Research which is freely available for redistribution

Submit your manuscript at www.biomedcentral.com/submit 